\title{
Commentary: This port's for YOU!
}

\author{
DuyKhanh P. Ceppa, MD
}

In December of 2019, Chinese officials acknowledged a new, highly contagious virus that resulted in pneumonia and an extreme acute respiratory distress syndrome, resulting in more deaths than influenza or severe acute respiratory syndrome coronavirus (SARS-CoV). By January 2020, cases of SARS-CoV-2 were being reported around the world, and the World Health Organization declared a Public Health Emergency of International Concern on January $30,2020 .{ }^{1}$ The contagion of this virus and its deadliness are real. ${ }^{2}$ In particular, health care professionals on the frontline of care are being exposed to greater viral loads due to multiple exposures and, despite the lack of comorbid conditions, presumably young and healthy physicians are, too, succumbing to the virus. Even more insidious is the fact that carriers of the virus may be asymptomatic for days to weeks or may have only mild symptoms. All the while these asymptomatic or mildly symptomatic patients are shedding the virus and, unknowingly, infecting those around them.

Performing surgery (either elective or urgent) on an asymptomatic carrier of SARS-CoV-2 is a possibility. Moreover, becoming infected by an unsuspecting carrier has occurred, and surgeons have fallen ill. ${ }^{3}$ During this new "post-coronavirus disease 2019 (COVID-19)" era, establishing safeguards and minimizing exposure and infection are paramount to the surgeon and the entire operating room team. In their techniques manuscript, Seco and colleagues ${ }^{4}$ describe such a process, which is especially important to the discipline of general thoracic surgery and pulmonary resections.

\footnotetext{
From the Division of Cardiothoracic Surgery, Department of Surgery, Indiana University School of Medicine, Indianapolis, Ind.

Disclosures: The author reported no conflicts of interest.

The Journal policy requires editors and reviewers to disclose conflicts of interest and to decline handling or reviewing manuscripts for which they may have a conflict of interest. The editors and reviewers of this article have no conflicts of interest.

Received for publication May 26, 2020; revisions received May 26, 2020; accepted for publication May 28, 2020; available ahead of print June 15, 2020

Address for reprints: DuyKhanh P. Ceppa, MD, Division of Cardiothoracic Surgery, Department of Surgery, Indiana University School of Medicine, 545 Barnhill Dr, EH215, Indianapolis, IN 46228 (E-mail: dpceppa@iupui.edu).

JTCVS Techniques 2020;3:417-8

2666-2507

Copyright (C) 2020 The Authors. Published by Elsevier Inc. on behalf of The American Association for Thoracic Surgery. This is an open access article under the CC BY-NCND license (http://creativecommons.org/licenses/by-nc-nd/4.0/).

https://doi.org/10.1016/j.xjtc.2020.05.027
}

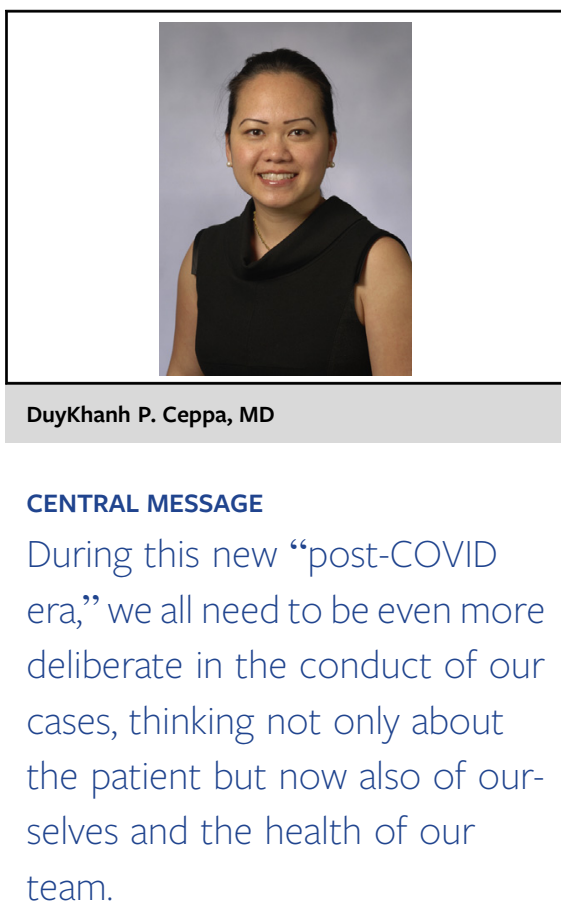

Identified as critical to performing intrathoracic surgery during the "COVID" era are (1) preoperative screening, (2) minimizing aerosolization during surgery with specific insufflation/desufflation ports, and (3) minimizing aerosolization during surgery by limiting instrument exchange and tissue handling. The authors screen elective patients with nasopharyngeal swabs within 48 hours of elective surgery. A computed tomography scan of the chest is also performed, ideally within 48 hours of surgery. Intraoperatively, the authors limit potential exposure during port placement by using lowpressure insufflation. The port system the authors describe suctions out all intrathoracic gases before port and instrument exchanges. Smoke-inducing energy devices have accompanying smoke evacuation. All suctioned gases are filtered. Finally, specimens are set aside in the chest in separate but labeled "bags" and only retrieved once at the end of the operation before skin closure.

While the authors skillfully describe their process and technique, they, unfortunately, do not yet have data that this technique is successful in limiting exposure and infections in patients positive for COVID-19. This manuscript does, however, raise a few interesting questions to contemplate. In the era of COVID-19, as aerosolization is easier to control or limit using small incisions and minimally invasive techniques, should we as a community strive even 
harder to increase the adoption of minimally invasive surgery across all surgeon generations? In traditional thoracoscopic surgery, sealed ports, insufflation, and desufflation are not typically used. Should thoracoscopic surgeons adopt the use of these devices? Or, more controversially, should thoracoscopic surgeons convert to robotic surgery? The answers to those questions are well beyond the scope of this manuscript and this editorial. However, it is clear that during this new "post-COVID era," whether we adopt Seco and colleague's technique or another, we all need to be even more deliberate in the conduct of our cases, thinking not only about the patient and their disease process but now also of ourselves and the health of our colleagues and team. So, SARS-CoV-2, this insufflation/desufflation port's for you!

\section{References}

1. World Health Organization. WHO Timeline-COVID-19. Available at: https:// www.who.int/news-room/detail/27-04-2020-who-timeline-covid-19. Accessed May 26, 2020

2. Johns Hopkins University \& Medicine. Coronavirus resource center. Available at: https://coronavirus.jhu.edu/map.html. Accessed May 26, 2020.

3. Columbia University. After Recovering from COVID-19, Columbia Surgeon Sings. Available at: https://www.cuimc.columbia.edu/news/after-recoveringcovid-19-columbia-surgeon-sings. Accessed May 26, 2020.

4. Seco M, Wood J, Wilson MMK. COVIDSafe thoracic surgery: minimizing intraoperative exposure to aerosols. J Thorac Cardiovasc Surg Tech. 2020;3: 412-4. 